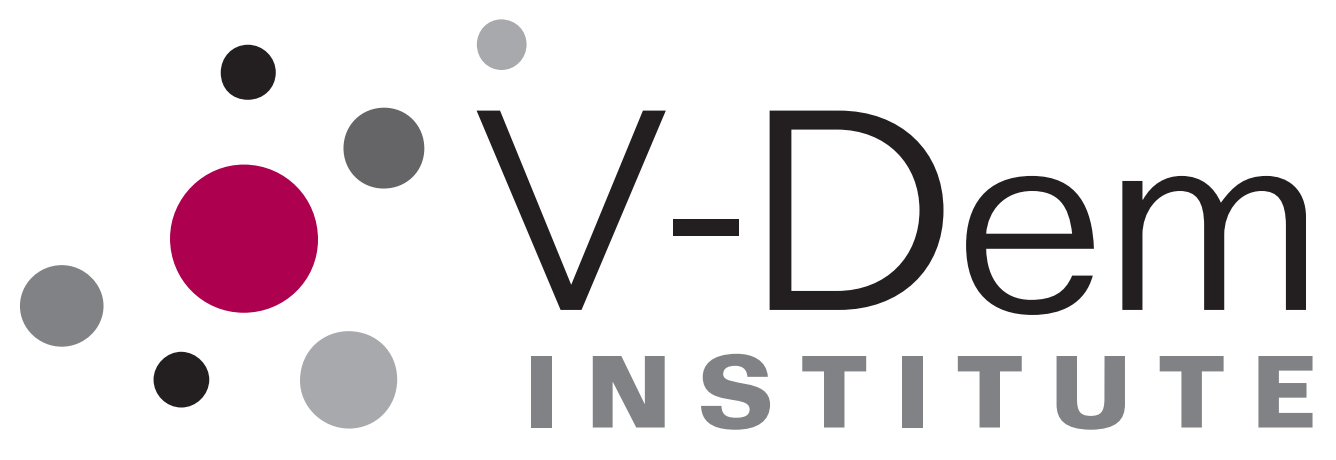

00000000000000000000 000000000000000000000000

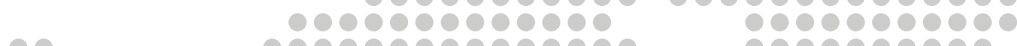

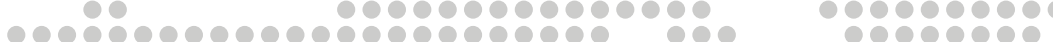

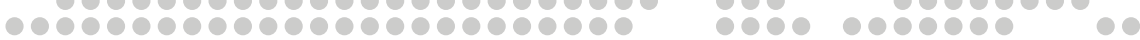

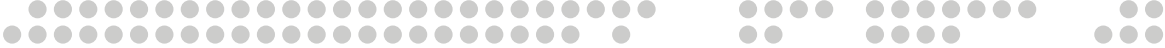


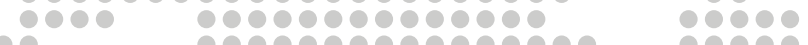

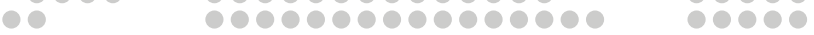

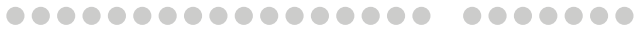
0000000000000000000000000

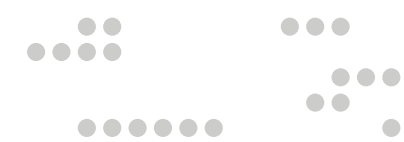

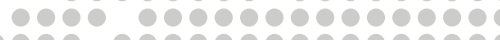

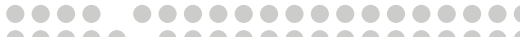
000000000000000000 c0

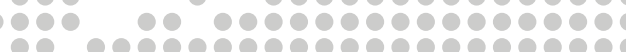

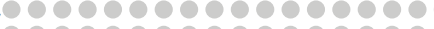
(10000000000000000

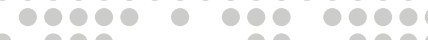

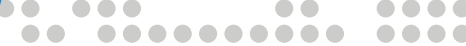

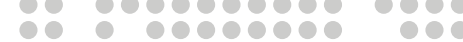

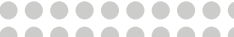

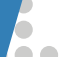

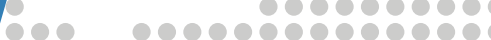

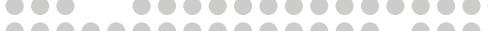

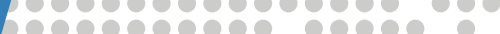

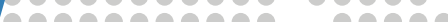
19808-

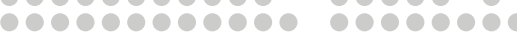
Anna Lührmann Bryan Rooney \section{States of Emergency and Democratic Decline \\ Autocratization by Decree:}


Varieties of Democracy (V-Dem) is a new approach to conceptualization and measurement of democracy. The headquarters - the V-Dem Institute - is based at the University of Gothenburg with 19 staff. The project includes a worldwide team with six Principal Investigators, 14 Project Managers, 30 Regional Managers, 170 Country Coordinators, Research Assistants, and 3,000 Country Experts. The V-Dem project is one of the largest ever social science research-oriented data collection programs.

Please address comments and/or queries for information to:

V-Dem Institute

Department of Political Science

University of Gothenburg

Sprängkullsgatan 19, PO Box 711

SE 40530 Gothenburg

Sweden

E-mail: contact@v-dem.net

V-Dem Working Papers are available in electronic format at www.v-dem.net.

Copyright (C2020 by authors. All rights reserved. 


\title{
Autocratization by Decree: States of Emergency and Democratic Decline *
}

\author{
Anna Lührmann \\ V-Dem Institute/University of Gothenburg \\ Bryan Rooney \\ RAND Cooperation
}

* This paper is forthcoming in Comparative Politics. This research was supported by Vetenskapsrådet [grant
number 2018-016114], PI: Anna Lührmann and European Research Council, Grant 724191, PI: Staffan I.
Lindberg, V-Dem Institute, University of Gothenburg, Sweden as well as by internal grants from the Vice-
Chancellors office, the Dean of the College of Social Sciences, and the Department of Political Science at
University of Gothenburg. We are grateful for Philipp Toenjes' and Sandra Grahn's skillful research assistance. 


\begin{abstract}
States of emergency grant chief executives the power to bypass democratic constraints in order to combat existential threats. As such they are ideal tools to erode democratic institutions while maintaining the illusion of constitutional legitimacy. Therefore, states of emergency should be associated with a heightened risk of autocratization - a decline in a regime's democratic attributes. Despite this theoretical link and the contemporary relevance of both autocratization and states of emergency, no prior study has empirically tested this relationship. This paper tests this relationship using data on sixty democracies for 1974 to 2016 . We find that democracies are 75 percent more likely to erode under a state of emergency. This evidence strongly suggests that states of emergency circumvent democratic processes in ways that might inspire democratic decline.
\end{abstract}




\section{Introduction}

On February $15^{\text {th }}, 2019$, President Donald Trump declared a national emergency on the southern border of the United States in an effort to circumvent Congressional will regarding the construction of a border wall. Although this is the fifty-ninth declared national emergency under the National Emergencies Act, its character has been challenged as out of line with previous practice, and his decision was met with fierce criticism. To cite just one such response, fifty-eight former prominent security officials have called this move "at odds with the overwhelming evidence in the public record, including the administration's own data and estimates." However, while such controversial use of the state of emergency has been uncommon throughout US history, President Trump is not the first democratically elected leader to be challenged for his use of emergency powers.

On July 22nd, 2016, the Turkish president Recep Tayyip Erdoğan and his government declared a state of emergency - the first in history to encompass the entire state - in an attempt to "root out the virus" responsible for the coup attempt just one week prior. ${ }^{2}$ Under Article 119 of the Turkish Constitution of 1982, the President of the Republic and the Council of Ministers may declare a state of emergency in the event of "serious indications of widespread acts of violence aimed at the destruction of the free democratic order established by the Constitution or of fundamental rights and freedoms." Once an emergency has been declared, the President "may issue decrees having the force of law on matters necessitated by the state of emergency (Article 121)." Under these emergency powers, Erdoğan and the Turkish government jailed more than 40,000 people accused of plotting the failed coup, dismissed more than 140,000 people from their jobs, shut down 1,500 civil groups, and virtually removed freedom of the press by arresting journalists and closing independent media outlets. ${ }^{3}$ Though the state of emergency was scheduled to last for three months, the state of emergency persisted until July 2018 over two full years - ending only after Erdoğan had won reelection. Through the use of his emergency powers, Erdoğan has de-facto transformed Turkey into a presidential. 4

The extension of political power to the executive in times of real or manufactured crisis is not contained to the US or the Turkish case. Constitutions frequently allow the executive to centralize power when confronted by a heightened threat. ${ }^{5}$ From 1800 to 2012, eighty democracies approved legal provisions for a state of emergency, specifying how the government is empowered to take

\footnotetext{
${ }^{1}$ Joint Declaration of Former United States Government Officials (cdn.cnn.com/cnn/2019/images/02/25/20192-21.final.national.emergency.decl.pdf).

${ }^{2}$ Erin Cunningham, and Hugh Naylor, "Turkish authorities granted emergency powers amid 'cleansing' after failed coup," Washington Post, Jul. 21, 2016; Mark Lowen, "Turkey coup attempt: State of emergency announced,"BBC News, Jul. 21, 2016.

3 Patrick Kingsley, "Turkish leader extends nation's state of emergency," The Boston Globe, May 21, 2017.

${ }^{4}$ Berk Esen, and Sebnem Gumuscu, “Turkey: How the Coup Failed,” Journal of Democracy, 28 (Jan. 2017), 59-73.

5 Clinton Rossiter, Constitutional Dictatorship (New Brunswick, N.J:Transaction Publishers,1948); John Ferejohn, and Pasquale Pasquino, "Law of Exception: A Typology of Emergency Powers," The International Journal of Constitutional Law, 2 (2004), 210-239.
} 
actions beyond its standard procedures in the event of international or domestic crisis. This accounts for over half of all democratic country-years during this time period. The descent of Turkey into dictatorship demonstrates how the effects of a state of emergency can be quite dramatic and longlasting. However, outside an examination of early $\operatorname{cases}^{6}$, we know very little about the relationship of the state of exception to autocratization. This is a notable omission in the literature. Autocratization - the gradual or sudden decline of democratic regime attributes - is on the rise globally. ${ }^{7}$ Such processes can lead a country to be less democratic than before but remain a democracy. Some of the cases are severe enough for the country to cross the threshold between democracy and autocracy. It is therefore vital to understand better how autocratization unfolds and which factors foster the decline of democracy.

States of emergency may well be a crucial piece in better understanding processes of autocratization. They are more likely to be declared during periods of instability. Nevertheless, states of emergency do not necessarily lead to autocratization. If they are used by the elected executive to effectively and proportionately respond to a crisis situation, the quality of electoral democracy is not at stake. At the same time, chief executives with the intent to dismantle democracy can be considered more likely to invoke a state of emergency and - once it is in place - abuse the extraordinary powers that typically come with it. States of emergency present an opportunity for wannabe dictators to assume more power under the veneer of constitutional legitimacy. Once in place, they give leaders - as the example of Erdoğan demonstrates - additional power to mute dissent and centralize political authority. Thus, we expect that countries are more likely to undergo substantial autocratization when a state of emergency is declared.

The purpose of this paper is to empirically assess this hypothesis with the help of regression analysis on sixty democracies from 1974-2016. Our dependent variable indicates whether or not a country is undergoing a process of substantial autocratization based a concept introduced by Lührmann and Lindberg. ${ }^{8}$ Our variable of interest is the declaration of a state of emergency, using data from Hafner-Burton, Helfer and Fariss and the State Department's annual human rights reports. ${ }^{9}$ Our results suggest that countries with a state of emergency are indeed more likely to also undergo a period of democratic decline. In fact, we find that democracies are 75 percent more likely to erode under a state of emergency than without, marking a substantial increase in the probability of democratic decline, and this result is robust to a number of alternative specifications.

\footnotetext{
${ }^{6}$ Rossiter.

${ }^{7}$ We define autocratization as a decline in the electoral aspects of democracy - elected officials, universal suffrage, clean elections and freedom of association and expression. See the Research Design and Data section for further details. Anna Lührmann, and Staffan I. Lindberg, "A Third Wave of Autocratization is Here: What is New About It?” Democratization, 26 (Jan. 2019), 1-19.

${ }^{8}$ Ibid.

${ }^{9}$ Emilie M. Hafner-Burton, Laurence R. Helfer, and Christopher J. Fariss, "Emergency And Escape: Explaining Derogations From Human Rights Treaties,” International Organization, 65 (Oct. 2011), 673-707; U.S. State Department Human Rights Report (https://www.state.gov/j/drl/rls/hrrpt/humanrightsreport/).
} 
We proceed as follows. First, we discuss the origins and application of states of emergency. We take specific note of how states of emergency empower executives. Then, we discuss the state of the art on the relationship between states of emergency and autocratization, followed by the development of our theoretical argument. Subsequently we introduce our data sources and research design. The final sections discuss the empirical findings and conclusions.

\section{States of Emergency and Executive Empowerment}

The state of emergency refers to the mechanism by which, in times of imminent danger, the government is empowered to take actions beyond its standard procedures. The modern use of this mechanism can be traced back to the Roman Republic, where in times of national emergency, the Roman consuls would nominate a dictator who had nearly absolute power to take action free from the standard political institutions. ${ }^{10}$ Today, emergency provisions are common features of democratic states with a variety of institutional arrangements, designed to overcome restraints on necessary action during periods of national distress. Recent work, for example by Bjørnskov and Voigt, and Rooney, help explain why and how political elites might introduce emergency powers into constitutions. ${ }^{11}$ The decision to implement such provisions derives from historical experiences such as international conflict, internal discord, and economic crisis, amongst myriad other factors. ${ }^{12} \mathrm{We}$ build on this work by focusing instead on the content and consequences of these provisions.

Specifically, we note the role of the state of emergency in substantially increasing executive empowerment. First, there are often few limitations on the ability of the executive to declare an emergency. Each emergency provision highlights the extraordinary nature of the threat to the democratic order and national survival. The Serbian Constitution of 2006 allows the declaration of a state of emergency "when the survival of the state or its citizens is threatened by a public danger (Article 200)." The Paraguayan Constitution of 1992 calls for the declaration of a state of exception in "the case of an armed international conflict, formally declared or not, or of a grave internal commotion that puts in imminent danger the rule of this Constitution or the regular functioning of the organs created by it (Article 288)." However, the causes of such an extraordinary threat can vary

\footnotetext{
${ }^{10}$ Rossiter.

${ }^{11}$ Christian Bjørnskov, and Stefan Voigt, "Why Do Governments Call a State of Emergency? On the Determinants of Using Emergency Constitutions," European Journal of Political Economy, 54 (Sep. 2018), 110-123; Bryan Rooney, "Emergency Powers in Democratic States: Introducing the Democratic Emergency Powers Dataset," Research \& Politics, 6 (Dec. 2019a), 1-7.

12 Jean Foyer, "The Drafting of the French Constitution of 1958," in Robert A. Goldwin and Art Kaufman, eds., Constitution Makers on Constitution Making (Washington, DC.: American Enterprise Institute, 1988); Constantine Tsatsos, "Making the Constitution of Greece," in Robert A. Goldwin and Art Kaufman, eds., Constitution Makers on Constitution Making (Washington, DC.: American Enterprise Institute, 1988); Gustavo Planchart Manrique, "The Making of the Venezuelan Constitution," in Robert A. Goldwin and Art Kaufman, eds., Constitution Makers on Constitution Making (Washington, DC.: American Enterprise Institute, 1988).
} 
widely. Nearly every emergency provision covers an external opponent. Yet while some emergency provisions only allow extraordinary action following an attack against the state, the government, or its people, this is relatively uncommon - only 15 percent of states restrict the use of emergency powers in this fashion. The majority further provide measures to combat a domestic threat, be it rebellion, economic crisis, or disaster. ${ }^{13}$

In fact, emergency provisions often provide little specificity of which actions short of open warfare warrant the declaration of a state of emergency. The Indian Constitutional Amendment of 1978 serves as a prime example, stating, "A Proclamation of Emergency declaring that the security of India or any part of the territory thereof is threatened by war or by external aggression or by armed rebellion may be made before the actual occurrence of war or of any such aggression or rebellion, if the President is satisfied that there is imminent danger thereof (Article 37, Amendment of Article 352)." A looming threat can be grounds for a declaration of a state of emergency, before an internal or external opponent even initiates military action.

As a consequence, the invocation of emergency provisions varies dramatically but can reach great frequency. While India has declared a state of emergency just three times, the use of Necessity and Urgency Decrees in Argentina reached an average of 54.5 decrees per year during the presidency of Carlos Menem, 36.5 decrees per year during the two years of Fernando de la Rua's presidency, and 60 decrees per year under Nestor Kirchner. ${ }^{14}$ Such frequent use of a state of exception has perhaps rendered their presence non-threatening to the democratic process in Argentina. Yet repeated use of these states of emergency were evidence of democratic decline in the Philippines. In 2001, President Gloria Macapagal-Arroyo declared a state of exception following protests in response to the arrest of former President Joseph Estrada, a tool she would use again in 2003, 2006, and 2009. The fluidity of use of states of emergency means that executives are often empowered to activate this mechanism whenever they require.

This freedom of action granted to the leader drives executive empowerment due to the content of the provisions themselves. ${ }^{15}$ There are a number of cases in which nations have designed their emergency provisions so as to maintain the underlying separation of powers in the government even in a crisis. Under the Constitution of Kenya enacted in 2010, during a state of emergency the President and his National Security Council may "integrate the domestic, foreign and military policies relating to national security in order to enable the national security organs to cooperate and function effectively." However, this is only possible if the National Assembly supports the

\footnotetext{
${ }^{13}$ Descriptive statistics on emergency powers come from Rooney, 2019a.

${ }^{14}$ This variation occurs for two reasons. First, states have varying formal circumstances in which emergency provisions can be invoked and varying norms of invocation. Second, the events that lead to invocation are not distributed evenly among states. Some states are simply more likely to encounter international foes, terrorist violence, domestic disturbances, or natural disasters. La Nacion, "Kirchner firócada seis días un decreto de necesidad y urgencia." Apr. 13, 2008.

${ }^{15}$ Not all emergency provisions contain such features. In 12 percent of emergency provisions, the leader may declare a state of emergency, but possesses no further power.
} 
declaration of emergency via a two-thirds vote within fourteen days. Further, each declaration is subject to Supreme Court review, and the President requires parliamentary support both for the passing of legislation and the deployment of the armed forces (Constitution of Kenya, 2010, Articles 58 and 240). The executive can direct national policy when the extremity of circumstances dictates, but only subject to a number of checks on their power.

When emergency provisions do delineate procedural tools that the executive may utilize in times of crisis, however, many of these tools stretch into the standard workings of government. The Honduran Constitution of 1982 states that the executive may "incur loans, change the purpose of an authorized item, or open additional credits for satisfying urgent or unforeseen needs in the event of war, internal disturbance or public disaster" (Article 365)." Emergency provisions are often even more encompassing, dramatically altering the political landscape through granting the leader broad, sweeping power. The Taiwanese Constitution of 1994 states that during a period of emergency the President may "take all necessary measures to avert imminent danger affecting the security of the State or of the people or to cope with any serious financial or economic crisis (Article 4)," granting broad powers to combat a broad array of ills. Often emergency provisions grant the executive the ability to make declarations of policy that immediately become law. The Slovenian Constitution of 1991 grants the government the ability to "issue decrees with the force of law (Article 108)" during a state of emergency or war. This level of executive power is dramatic, yet it is not uncommon - nearly 40 percent of emergency provisions grant this level of policy power. Further, only 55 percent of emergency provisions mandate that emergencies terminate within a specific time frame. Often emergencies can be renewed when exigencies demand it, which means nations may operate under a state of emergency well past the period of the initial crisis. ${ }^{16}$ The executive may therefore be empowered to take potentially non-democratic action for a substantial period of time.

With states of emergency allowing such dramatic derogation from the nation's standard institutions, even a single declared state of emergency can have a dramatic impact on the future of the nation. This has, however, seen very little attention in the quantitative literature. Much of this work arises from human rights scholars. While studies investigating the effect of de-jure provisions for emergency powers on de-facto human rights protections provide mixed results, their mixed findings are not surprising, as de-jure provisions can only have an effect on the human rights if they are de-facto implemented. ${ }^{17}$ Prior studies have compared the effects of de-facto declarations of state of emergencies: Richards and Clay show that governments are more likely to violate fundamental

\footnotetext{
16 The case of India following the Indo-Pakistani War of 1971 highlights this fact well (Omar 2002).

${ }^{17}$ Christian A. Davenport, "COnstitutional Promises' and Repressive Reality: A Cross- National Time-Series Investigation of Why Political and Civil Liberties are Suppressed," The Journal of Politics, 58 (Aug.1996), 627-654; Linda Camp, and Steven C. Poe, "Are Constitutional State of Emergency Clauses Effective-An Empirical Exploration,” Human Rights Quarterly, 26 (2004), 1071-1097.
} 
human rights during states of emergencies. ${ }^{18}$ Hafner-Burton, Helfer, and Fariss demonstrate that human rights treaties often allow derogations from civil liberty protections during periods of emergency, which governments utilize to avoid backlash from voters, the courts, and interest groups. ${ }^{19}$ Neumayer shows that this relationship applies most strongly for autocracies, to a lesser extent for hybrid regime and not at all for democracies. ${ }^{20}$ However, Rooney, providing a measure of the power granted to the leader during a state of exception, shows that democratic leaders with stronger institutional emergency powers are more prone to engage in armed conflict. ${ }^{21}$

Scholars have therefore suggested a number of pernicious consequences of states of emergencies. However, these recent empirical advances have not yet been applied to a full consideration of the effects of states of emergency on the nation. Specifically, scholars have yet to provide a theoretical framework or empirical analysis of perhaps the most critical of consequences - the relationship between a declared state of emergency and the likelihood a democratic state experiences autocratization.

\section{Autocratization and Emergency}

Recent democratic setbacks in a variety of countries - Hungary, Brazil, Poland, Turkey, Russia, to name only a few - have sparked a new generation of studies on autocratization. It seems that we are witnessing the early stages of a global reversal in democratization. ${ }^{22}$ We define this reversal, encompassing any move away from full democracy, as autocratization. ${ }^{23}$ Such processes may lead to democratic breakdown or merely the democratic erosion within the democratic regime spectrum.

${ }^{18}$ David L. Richards, and K. Chad Clay, “An Umbrella with Holes: Respect For Non-derogable Human Rights During Declared States of Emergency, 1996-2004,” Human Rights Review, 13 (Nov. 2012), 443-471.

${ }^{19}$ Hafner-Burton et al..

${ }^{20}$ Eric Neumayer, "Do Governments Mean Business When They Derogate? Human Rights Violations During Notified States of Emergency," The Review of International Organizations, 8 (May 2013), 1-31.

${ }^{21}$ Bryan Rooney, "Emergency Powers in Democracies and International Conflict," Journal of Conflict Resolution, 63 (Feb. 2019), 644-671.

22 Nancy Bermeo, “On Democratic Backsliding,” Journal of Democracy, 27 (Jan. 2016), 5-19; Larry Diamond, "Facing Up to the Democratic Recession," Journal of Democracy 26 (Jan. 2015), 141-155; Joshua Kurlantzick, Democracy in Retreat: The Revolt of the Middle Class and the Worldwide Decline of Representative Government (New Haven, CT: Yale University Press, 2013); Steven Levitsky, and Daniel Ziblatt, How Democracies Die (London: Viking, 2018); Valeriya Mechkova, Anna Lührmann, and Staffan I. Lindberg, "How Much Democratic Backsliding?” Journal of Democracy, 28 (Oct. 2017), 162169.

${ }^{23}$ Cassani and Tomini elaborate on the debate over this term in great detail, and define autocratization positively as a "process of regime change towards autocracy that makes politics increasingly exclusive and monopolistic, and political power increasingly repressive and arbitrary." We instead follow Lührmann and Lindberg and define the term negatively, as a move away from democracy, to treat democratization and autocratization as mutually exclusive. Andrea Cassani, and Luca Tomini, "Reversing Regimes and Concepts: From Democratization to Autocratization," European Political Science (May 2018), 1-16; Lührmann and Lindberg. 
Contemporary autocratization is an often gradual, protracted process led by incumbent political elites. ${ }^{24}$ As Svolik points out, such autogolpes - "transitions to authoritarianism caused by the incumbent chief executive" - occur even in mature democracies. ${ }^{25}$ Coppedge identified the gradual concentration of executive power as a key pattern of contemporary autocratization. ${ }^{26}$ This form of executive aggrandizement, in which elected executives weaken checks on executive power one by one, undertaking a series of institutional changes that hamper the power of opposition forces to challenge executive preferences, has become more prominent than sudden regime change. ${ }^{27}$ Incumbent elites are substituting highly visible methods, such as military coups and electoral fraud, with more clandestine tactics like harassment of the media, repression of the opposition, and the general subversion of horizontal accountability mechanisms. ${ }^{28}$

Case studies provide some insights that states of emergency have helped to break down democracies or orchestrate further retraction in autocracies in this manner - for instance in Latin America, Asia, Egypt, Ethiopia and Turkey. ${ }^{29}$ Yet to our knowledge, no prior comparative study exists on how incumbents use states of emergencies to foster autocratization, and most studies on emergency powers do not include systematic comparisons of de-facto effects. ${ }^{30}$ The classical work on emergency powers in the field of legal and philosophical studies emphasized the danger of 'constitutional dictatorships' turning 'unconstitutional' when leaders abused their powers to undermine democratic institutions - a debate that has been revived in recent years. ${ }^{31}$ In the following

24 Bermeo 2016; Diamond; Michael Coppedge, “Eroding Regimes: What, Where, and When?” V arieties of Democracy (V-Dem) Institute Working paper, 57 (Nov. 2017), 1-30; Anna Lührmann, Valeriya Mechkova, Sirianne Dahlum, Laura Maxwell, Moa Olin, Constanza Sanhueza Petrarca, Rachel Sigman, Matthew C. Wilson, and Staffan I. Lindberg. "State of the World 2017: Autocratization and Exclusion?” Democratization, 25 (Jun. 2018), 1321-1340; Mechkova et al.; David Runciman, How Democracy Ends (London: Profile Books, 2018).

${ }_{25}$ Milan W. Svolik, "Which Democracies Will Last? Coups, Incumbent Takeovers and the Dynamic of Democratic Consolidation," British Journal of Political Science, 45 (Oct. 2015), 715- 738; Adam Przeworski, Michael E. Alvarez, José Antonio Cheibub, and Fernando Limongi, Democracy and Development: Political Institutions and Well-Being in the World, 19501990 (Cambridge: Cambridge University Press, 2000), p.21.

${ }^{26}$ Coppedge.

${ }^{27}$ Bermeo, 2016.

${ }^{28}$ Lührmann et al., 2018.

${ }^{29}$ Brian Loveman, The Constitution of Tyranny: Regimes of Exception in Spanish America (Pittsburg: Univ of Pittsburgh Press, 1993); Sadiq Reza, "Endless Emergency: The Case of Egypt," New Criminal Law Review: In International and Interdisciplinary Journal, 10 (2007), 532-553; Pietro S. Toggia, “The State of Emergency: Police and Carceral Regimes in Modern Ethiopia," Journal of Developing Societies, 24 (June 2008), 107-124; Victor V. Ramraj, and Arun K. Thiruvengadam, Emergency Powers in Asia: Exploring the Limits of Legality (Cambridge: Cambridge University Press, 2009); Ece Göztepe, “The Permanency of the State of Emergency in Turkey," Zeitschrift für Politikwissenschaft, 28 (Oct. 2018), 521-534.

${ }^{30}$ For a seminal example see Gross and Aoláin. Oren Gross, and Fionnuala Ní Aoláin, Law in Times of Crisis: Emergency Powers in Theory and Practice Vol. 46, (Cambridge: Cambridge University Press, 2006).

${ }^{31}$ Rossiter; Frederick M. Watkins, “The Problem of Constitutional Dictatorship,” Public Policy, 1 (1940), 324-379; Carl J. Friedrich, "Military Government and Dictatorship," The Annals of the American Academy of Political and Social Science, 267 (1950), 1-7; Bruce Ackerman, “The Emergency Constitution,” Yale Law Journal, 113 (2003), 1029-1092; Giorgio Agamben, State of Exception, Vol. 2 (Chicago: University of Chicago Press, 2005); David Dyzenhaus, The Constitution of Law: Legality in a Time of Emergency (Cambridge: Cambridge University Press, 2006); Matthias Lemke, “What Does State of Exception Mean?” Zeitschrift für Politikwissenschaft, 28 (Sep. 2018), 373-383. 
section, we consider this how these common legal provisions may indeed have a substantial impact on the likelihood of autocratization.

\section{A Theory of States of Emergency and Autocratization}

States of emergency have a dual role in their relationship with autocratization. States of emergency are more likely to be declared in times of political instability, when the nation is more vulnerable for autocratization. Official explanation of declarations of emergency arise from such wide-ranging causes such as domestic protest (Mongolia, 2008), natural disasters (Sri Lanka, 2004), coup attempts (Trinidad and Tobago, 1990), international war (India, 1971), terrorism (France, 2015), and economic crisis (Argentina, 2001), among others. Each of these events might make the nation more susceptible to democratic decline. States of emergency may therefore exhibit an indirect connection to democratic decline simply by virtue of their role in marking the state's insecurity.

Yet the mere declaration of a state of emergency, by itself, need not erode democracy, and might even be seen as a guard against democratic decline. If the use of such emergency powers is constrained to truly existential threats to the nation, or if the state returns to its standard institutions after the emergency subsides, the state of emergency has performed its function well, and democracy has remained unchallenged. Indeed, this is the key difference between a state of emergency itself and autocratization: The first is a temporary institutional derogation whereas the second constitutes a dramatic institutional shift.

However, we argue that periods of emergency have not only an indirect relationship with autocratization, but also a direct effect on such processes. As we have described, under the state of emergency, leaders have the opportunity to both extend their control past the realm of the emergency and even past the duration of the emergency. Emergency powers, when enacted, create political openings for changes that the leader may otherwise not be able to make. Therefore, states of emergency can be a useful tool for the leader in expanding her power and removing democratic constraints. ${ }^{32}$

Gaining more power over state resources is a key reason why incumbents push their country towards autocracy. ${ }^{33}$ For instance, Peruvian President Alberto Fujimori decided to dissolve the parliament in 1992 and assume dictatorial powers out of frustration about the need to compromise

\footnotetext{
${ }^{32}$ For a similar argument, see Levitsky and Ziblatt, 92-96.

33 Bermeo, 2016.
} 
with other actors under democratic rule. ${ }^{34}$ Two different sets of constraints on incumbents are common in democracies - a modern public administration and accountability relationships. First, a modern public administration - the rule of law and an impartial public administration - limits incumbents' access to state resources. ${ }^{35}$ Thus, even though they have reached the most powerful state office, incumbents cannot arbitrarily use state resources for their personal ends or without following a prescribed set of procedures. Second, various accountability relationships constrain the power of elected officials in democracies. It is common to distinguish between vertical (related to elections and political parties), horizontal (checks and balances between institutions), and diagonal (media and civil society) dimensions of accountability. ${ }^{36}$ States of emergency can help leaders to subvert the constraints of democratic procedure and the separation of powers.

In particular, states of emergency provide an opportunity structure for leaders to subvert democratic rule as they reduce the costs associated with such actions. In normal times, the expansion of executive power - particularly if done rapidly - is risky for leaders. Prior research clearly shows that most democracies erode slowly in recent decades. In a day and age where multi-party elections have become the global norm, even dictators invest a lot in appearing as democratic as possible. ${ }^{37}$ Sudden moves towards autocracy - such as military coups - risk triggering mass uprisings or international interventions. Thus, wannabe dictators would prefer to manipulate elections and gradually expand their power. In periods of emergency, the expansion of executive power is expected. States of emergency allow to the leader to combat an immediate threat to the nation by making use of previously unavailable powers.

A state of emergency does not only provide leaders with the opportunity to use additional powers. It also a offers them a good argument for why they need more power. Why should they have to bother with human rights and legislative, judicial, or other institutional constraints while the country is under attack? Thus, states of emergencies can help to dismantle democracy and subvert resistance to its demise. The opposition can easily be labeled as unpatriotic for challenging the government at a time when the state is imperiled and unity is required. Such proclamations were made by Indira Gandhi's government after it declared a state of emergency in 1971 in response to war with Pakistan, even as the government allowed emergency conditions to persist well after the war had ended. Thus, states of emergency are an ideal tool to undermine democracy under the guise of democratic and constitutional legitimacy.

This in turn has an effect on the possibility a state of emergency will be declared. All else being equal, an authoritarian-leaning leader is more likely to declare a state of emergency in a period of

\footnotetext{
${ }^{34}$ Nancy Bermeo, Ordinary People in Extraordinary Times - The Citizenry and the Breakdown of Democracy (Princeton, NJ: Princeton University Press, 2003).

35 Wolfgang Merkel, “Are Dictatorships Returning? Revisiting the 'Democratic Rollback' Hypothesis,” Contemporary Politics, 16 (Mar. 2010), 17-31.

${ }^{36}$ Mechkova et al..

${ }^{37}$ Bermeo, 2016; Lührmann and Lindberg.
} 
crisis. With few exceptions, scholars have scarcely considered why political elites declare emergencies. ${ }^{38}$ We argue that leaders who see little normative value in the institutions of democracy or those who care not about the precedent of derogation from democracy for future leaders will have little hesitation in bringing the nation outside of democratic norms, and thus emergencies may be declared even when the level of threat facing the nation is low.

Further, when a leader declares an emergency during a period of instability and in doing so constrains the freedom of action of the opposition, this may be seen as an important derogation from democracy by the opposition - and perhaps the public. ${ }^{39}$ The opposition may then feel free to take extra-democratic measures as well. If the opposition does take power, they have little incentive to return to the previous rules of democracy as they attempt to solidify control of the nation. When President of Madagascar Didier Ratsiraka declared a state of emergency following protests challenging the state's 2001 election results, the subsequent struggle led to a derogation from democracy that persisted even when the opposition had taken office.

In sum, authoritarian-leaning chief executives in democracies should both be more likely to declare a state of emergency and, once it is declared, abuse the powers it grants to dismantle democratic institutions. Therefore, we expect states of emergency to be associated with a heightened risk of autocratization - substantial declines in democratic regime attributes -even when accounting for factors that make a crisis itself dangerous.

\section{Research Design and Data}

\section{Dependent variable: Autocratization year}

As discussed above, we understand autocratization as any decline in the democratic quality of a regime - be it sudden or gradual. Conventional measures of adverse regime change have substantial weaknesses in capturing such processes. One prominent approach uses binary measures of democratic regime breakdown for their empirical analysis. ${ }^{40}$ However, this approach does not capture the often gradual processes of autocratization that we have described above and which often start way before the threshold to autocracy is crossed. ${ }^{41}$ The other approach uses annual changes in the level of democracy measures - such as POLITY, Freedom House, or V-Dem - as an indicator

\footnotetext{
38 Bjørnskov and Voigt, 2018.

39 This remains an open question to be tested by further analysis.

${ }^{40}$ For example, Juan J.Linz, and Alfred Stepan, The Breakdown of Democratic Regimes (Baltimore, MD: The Johns Hopkins University Press, 1978); Svolik.

${ }^{41}$ See also Bermeo, 2016.
} 
of regime change. ${ }^{42}$ The weakness of this modeling strategy is that it assumes that upward and downward trends are driven by the same factors. However, we know that several factors - for instance states of emergency - are likely to affect downward trends more than upward development and viceversa. 43

Lührmann and Lindberg have suggested a new measure that fits better to our purpose of isolating the relationship between states of emergencies and adverse regime change - be it gradual or sudden. ${ }^{44}$ To capture the often gradual process of autocratization, they use V-Dem's Electoral Democracy Index (EDI), which measures the extent to which a regime achieves the core institutional requirements in Dahl's conceptualization of electoral democracy as polyarchy. ${ }^{45} \mathrm{It}$ includes expert-coded measures on free and fair elections, universalsuffrage as well as freedom of speech, themediaandassociation. ${ }^{46}$ As such, theEDI not only captures the de-jure requirements of a democracy, but also the de-facto implementations of such democratic norms - for instance that pluralist perspectives are represented in the media. Since autocratizers often target such "soft" norms and institutions, the EDI is particularly well-suited to capture autocratization processes.

The EDI runs on a continuous scale from zero to one, with higher values indicating a more democratic regime. Based on Lührmann and Lindberg we define autocratization episodes as a substantial decline (a decrease of 10 percent or more) in a country's EDI score within one year or cumulatively across a consecutive period. ${ }^{47} \mathrm{~A}$ change of 10 percent is an intuitive choice for a cut-off point on a continuous, zero to one index. It is demanding enough to minimize the risk of measurement error or minor changes are driving the results. At the same time, it is low enough to capture incremental changes that do not amount to a full breakdown. $48 \mathrm{~A}$ potential autocratization episode starts with a decline in the EDI of 0.01 points or more from one year to the next. It continues in the next year if the EDI declines further or if it remains stagnate for no more than three consecutive years. A potential episode ends on the fourth year of stagnation or if the

42 Jan Teorell, Determinants of Democratization. (Cambridge, Cambridge University Press, 2010); Stephan Haggard, and Robert R. Kaufman, Dictators and Democrats - Masses, Elites and Regime Change (Princeton, NJ: Princeton University Press, 2016).

${ }^{43}$ To mitigate this problem, Teorell uses change in a combined Freedom House and Polity measure as dependent variable and sets all upturns to zero for the analysis of downturns. However, this approach does not help to differentiate between small declines on a democracy index that might be due to measurement error and the beginning of a more substantial downward turn. Further, constraining all upturns to zero creates a number of problems for statistical analysis. Claire Wright, Emergency Politics in the Third Wave of Democracy: A Study of Regimes of Exception in Bolivia, Ecuador, and Peru (Lanham, MD: Lexington Books, 2015); Teorell.

${ }^{44}$ Lührmann and Lindberg.

${ }^{45}$ Robert A. Dahl, Polyarchy: Participation and Opposition (New Haven, CT: Yale University Press, 1971); Robert A. Dahl, "Justifying Democracy," Society, 35 (Jan 1998), 386-392.

${ }^{46} \mathrm{~V}$-Dem relies on the assessment of more than 3,000 country experts to build its vaster range of indicators on more than 300 aspects of democracy. Typically, five experts provide an assessment per indicator and country. A custom build IRT-model then aggregates the rating taking differences in scale perception into account in order to ensure cross-national and temporal comparability. Daniel Pemstein, Kyle L. Marquardt, Eitan Tzelgov, Yi-ting Wang, Joshua Krusell, and Farhad Miri, “The V-Dem Measurement Model: Latent Variable Analysis for Cross-national and Cross-temporal Expert-coded Data," V-Dem Working Paper, 21 (Mar. 2020), 1-30.

${ }^{47}$ Lührmann and Lindberg.

${ }^{48}$ For more details, see Lührmann and Lindberg. 
EDI increases by 0.02 or more. To identify whether or not a country qualified as a democracy before the beginning of an autocratization episode, we use the relatively ambitious Regimes of the World measure, which indicates whether or not countries achieve a sufficient level of democratic guarantees as reflected in the EDI and other measures. ${ }^{49}$

There were fifty-four autocratization episodes in the V-Dem sample of democracies from 1974 to 2016 (roughly 6 percent of all country-year observations). Most (forty) of these episodes resulted in the breakdown of democracy, whereas fourteen entailed gradual declines within the democratic regime spectrum. Table 1.1 in the online appendix details all episodes. We focus in our analysis on the year of the beginning of an episode as dependent variable, since the measure captures the onset of autocratization, this allows us to test our notion that states of emergencies are likely to coincide with the beginning of autocratization. ${ }^{50}$

\section{Independent variable: States of emergency}

We use data on declared states of emergency from Hafner-Burton, Helfer and Fariss. ${ }^{51}$ They have coded a binary variable on whether or not a country was in a state of emergency based on the State Department's annual human rights reports for 1974 to $2006 .{ }^{52}$ We have updated the data for 2007-2016 based on reviewing the same source for those years. For the United States, we use data from the Brennan Center for Justice.

\section{Control variables}

We include a number of control variables to account for the possibility of a spurious relationship and to account for any indirect effect of the emergency itself on democratic decline. We expect that the more liberal institutions constrain the chief executive, the lower the risk of autocratization onset. ${ }^{3}$ Therefore, we control for the level of liberal democracy in the year prior using V-Dem's Liberal Component Indicator. ${ }^{54}$ This continuous index captures both the liberal

\footnotetext{
49 Anna Lührmann, Marcus Tannenberg, and Staffan I. Lindberg, "Regimes of the world (RoW): Opening New Avenues for the Comparative Study of Political Regimes," Politics and Governance, 6 (Jan. 2018), 60-78.

${ }^{50}$ In the appendix, we test for the effects in the year following a state of emergency, and find the results generally hold, though they are smaller and less significant.

${ }^{51}$ Hafner-Burton et al..

52 U.S. Department of State, Bureau of Democracy, Human Rights and Labor, Country Reports on Human Rights Practices for 2015 (2015) ( https://www.state.gov/j/drl/rls/hrrpt/humanrightsreport/).

${ }^{53}$ Lührmann and Lindberg.

${ }^{54}$ Michael Coppedge, John Gerring, Carl Henrik Knutsen, Staffan I. Lindberg, Svend-Erik Skaaning, Jan Teorell, David Altman, Michael Bernhard, Agnes Cornell, M. Steven Fish, Haakon Gjerløw, Adam Glynn, Allen Hicken, Joshua Krusell, Anna Lührmann, Kyle L. Marquardt, Kelly McMann, Valeriya Mechkova, Moa Olin, Pamela Paxton, Daniel Pemstein, Brigitte Seim, Rachel Sigman, Jeffrey Staton, Aksel Sundtröm, Eitan Tzelgov, Luca Uberti, Yi-ting Wang, Tore Wig, and Daniel Ziblatt, "V-Dem Codebook v8," V arieties of Democracy (V-Dem) Project, (Apr. 2018, 1-388); Michael Coppedge, John Gerring, Carl Henrik Knutsen, Staffan I. Lindberg, Svend-Erik Skaaning, Jan Teorell, David
} 
aspects of democracy such as legislative and judicial constraints on the executive and the rule of law. The variable is coded such that "zero" captures a state that is not democratic, while "one" captures a state that is fully democratic.

As most researchers believe that indicators of economic success are connected to autocratization and since a strong economy can protect against the ills of extraordinary events, we control for GDP per capita and GDP per capita growth. ${ }^{55}$ The data on GDP per capita levels and GDP per capita growth come from the Maddison project. ${ }^{56}$ We also include a control for economic gains from oil production, as a common theory states a negative relationship between an oil-based economy and democracy. ${ }^{57}$ We take these data from the Quality of Government project. ${ }^{58}$

Some scholars link globalization to dissatisfaction with democracy and thus an increased risk of emergency and autocratization. ${ }^{59}$ Data on economic globalization comes from the Konjunkturforschungsstelle (KOF) globalization dataset, and runs from zero to 100, with high values indicating more financial and trade globalization. ${ }^{60} \mathrm{~A}$ high level of political corruption might also affect satisfaction with democracy and make it difficult for the government to combat an emergency. ${ }^{61}$ We control for this factor with an index from the V-Dem project, with "zero" indicating low levels of corruption and "one" indicating high levels of corruption. ${ }^{62}$ Lastly, we also control for economic inequality using Gini data on disposable income from the Standardized World

Altman, Michael Bernhard, M. Steven Fish, Agnes Cornell, Sirianne Dahlum, Haakon Gjerløw, Adam Glynn, Allen Hicken, Joshua Krusell, Anna Lührmann, Kyle L. Marquardt, Kelly McMann, Valeriya Mechkova, Juraj Medzihorsky, Moa Olin, Pamela Paxton, Daniel Pemstein, Josefine Pernes, Johannes von Römer, Brigitte Seim, Rachel Sigman, Jeffrey Staton, Natalia Stepanova, Aksel Sundström, Eitan Tzelgov, Yi-ting Wang, Tore Wig, Steven Wilson, and Daniel Ziblatt, "V-Dem Dataset v8," Varieties of Democracy (V-Dem) Institute, (Apr. 2018) (https://www.vdem.net/en/data/data-version-8/).

${ }^{55}$ Haggard and Kaufman.

56 Angus "The Maddison, Maddison-Project,"

(http://www.ggdc.net/maddison/maddisonproject/home.html) 1:14.

57 Michael L. Ross, "Does Oil Hinder Democracy?” World Politics, 53 (Apr. 2001), 325-361.

58 Bo Rothstein, and Jan Teorell, "What is Quality of Government? A Theory of Impartial Government Institutions," Governance, 21 (Apr. 2008), 165-190.

59 Colin Crouch, Post-Democracy (Cambridge: Polity Cambridge, 2004).

${ }^{60}$ Konjunkturforschungsstelle, "KOF Index of Globalization" (2011) (https://kof.ethz.ch/en/forecasts-andindicators/indicators/kof-globalisation-index.html).

${ }^{61}$ Larry Diamond, “The Democratic Rollback: The Resurgence of the Predatory State,” Foreign Affairs, 87 (2008), 36-48.

${ }^{62}$ Michael Coppedge, John Gerring, Carl Henrik Knutsen, Staffan I. Lindberg, Svend-Erik Skaaning, Jan Teorell, David Altman, Michael Bernhard, Agnes Cornell, M. Steven Fish, Haakon Gjerløw, Adam Glynn, Allen Hicken, Joshua Krusell, Anna Lührmann, Kyle L. Marquardt, Kelly McMann, Valeriya Mechkova, Moa Olin, Pamela Paxton, Daniel Pemstein, Brigitte Seim, Rachel Sigman, Jeffrey Staton, Aksel Sundtröm, Eitan Tzelgov, Luca Uberti, Yi-ting Wang, Tore Wig, and Daniel Ziblatt, "V-Dem Codebook v8," Varieties of Democracy (V-Dem) Project, (Apr. 2018, 1-388); Michael Coppedge, John Gerring, Carl Henrik Knutsen, Staffan I. Lindberg, Svend-Erik Skaaning, Jan Teorell, David Altman, Michael Bernhard, M. Steven Fish, Agnes Cornell, Sirianne Dahlum, Haakon Gjerløw, Adam Glynn, Allen Hicken, Joshua Krusell, Anna Lührmann, Kyle L. Marquardt, Kelly McMann, Valeriya Mechkova, Juraj Medzihorsky, Moa Olin, Pamela Paxton, Daniel Pemstein, Josefine Pernes, Johannes von Römer, Brigitte Seim, Rachel Sigman, Jeffrey Staton, Natalia Stepanova, Aksel Sundström, Eitan Tzelgov, Yi-ting Wang, Tore Wig, Steven Wilson, and Daniel Ziblatt, "V-Dem Dataset v8," Varieties of Democracy (V-Dem) Institute, (Apr. 2018) (https://www.vdem.net/en/data/data-version-8/); Daniel Pemstein, Kyle L. Marquardt, Eitan Tzelgov, Yi-ting Wang, Joshua Krusell, and Farhad Miri, "The V-Dem measurement model: latent variable analysis for cross-national and cross-temporal expert-coded data," V-Dem Working Paper, 21 (Mar. 2020), 1-30. 
Income Inequality Database (SWIID), which runs from zero to 100, with high values indicating more inequality. ${ }^{63}$ The literature is undecided on the direction of the relationship of economic inequality with autocratization. Inequality may breed dissatisfaction with democracy on the side of citizens; at the same time elites may feel threatened by more egalitarianism and then challenge democracy. ${ }^{64}$

\section{Estimation strategy}

The dichotomous nature of our dependent variable - the occurrence of an autocratization episode in a given year, requires that we use probit models to evaluate our proposed hypothesis. We utilize probit models rather than alternative dichotomous variable models given the ability of the probit to account for both non-constant variance in our error and given the lack of extremity in the distribution of our independent variables. To account for potential endogeneity concerns, we lag all control variables by one year. ${ }^{65}$ We also include an estimation of a time trend, since rates of autocratization also correspond to the number of democratic states in the system. Finally, to help reduce the bias in our standard errors, we use bootstrapped standard errors.

\section{Results and Discussion}

We begin with some descriptive results. Over the last forty years, most (63 percent) democracies were in a state of emergency at least once. From 1974 to 2016, 8.3 percent of states of emergencies coincide with a period of substantial autocratization, while such episodes occur in just 5.2 percent of years without a state of emergency. This comprises 21.7 percent of the years with democratic decline in our sample. In most cases, such autocratization periods are lethal for democracies. We find that 90 percent of democracies collapsed during an autocratization episode with a state of emergency and only 10 percent survived. Conversely, 46 percent of democracies survived autocratization episodes without a state of emergency (Table 1.2 in the online appendix).

Thus, autocratization episodes with a state of emergency tend to be more severe for democracy than those without. Table 1.3 in the online appendix details which components of the Electoral Democracy Index deteriorate during an autocratization episode. Overall, the indices capturing freedom of expression, freedom of association, and free and fair elections experience the largest number of decreases. Very few states see changes in the elected officials index - which would signify abandonment of electoral processes - and none see changes in the suffrage indicator. However, the

\footnotetext{
${ }^{63}$ Frederick Solt, “The Standardized World Income Inequality Database (SWIID)”, Social Science Quarterly, 97 (May 2016), 1267-1281.

${ }^{64}$ Haggard and Kaufman.

${ }^{65}$ In the Appendix, we also lag our key independent variable, finding reduced but consistent effects.
} 
pattern for autocratization episodes looks different depending on whether or not a state of emergency was declared. During autocratization episodes with a state of emergency, more aspects of democracy deteriorate. For instance, while freedom of association deteriorates substantially in only in 29 percent of episodes without a state of emergency, it does so in 57 percent of the cases with a state of emergency. Further, in six cases with a state of emergency, even the elected officials index sees a substantial decline, which happens only once during a period of autocratization without a state of emergency.

In Figure 1, we provide a graphical depiction of electoral democracy in Sri Lanka, Venezuela, Moldova, and Nicaragua from 1990 to 2010, as an illustration of the relationship between states of emergencies and autocratization. These countries share a number of important differences, includingeach country's levelof democracy when the time frame begins. In each country, however, spells of autocratization coincide with a state of emergency. In each case, the states of emergency occur at the beginning of a dramatic trend, and additional states of emergency appear to coincide with further autocratization over time. This is true despite wide variation in the series of events inciting the state of emergency. In Sri Lanka in 2003, the emergency decree resulted from political turmoil during negotiations with the Liberation Tigers of Tamil Eelam. The Venezuelan government called a state of emergency as the result of a constitutional crisis. In Moldova, states of emergency were used to jail suspected terrorists in light of the conflict over Transnistria. In Nicaragua in 2005, the government declared a state of emergency in response to an economic and energy crisis. This substantial variety in inciting events suggests that there is something fundamental to the mechanism of the state of emergency that spurs democratic decline.

We now turn to our regression analysis in Table 1. To reiterate, we expect the occurrence of a state of emergency to be positively correlated with the occurrence of autocratization episodes. Model 1 fits the bivariate relationship and shows - as expected - a positive and statistically significant relationship. Model 2 adds the confounders discussed above. The focal relationship remains strong and statistically significant. The predicted probability of an autocratization episode is .04 without a declared state of emergency and .07 with one in place. Thus, with a state of emergency, countries are 75 percent more likely to decline than without a state of emergency. 

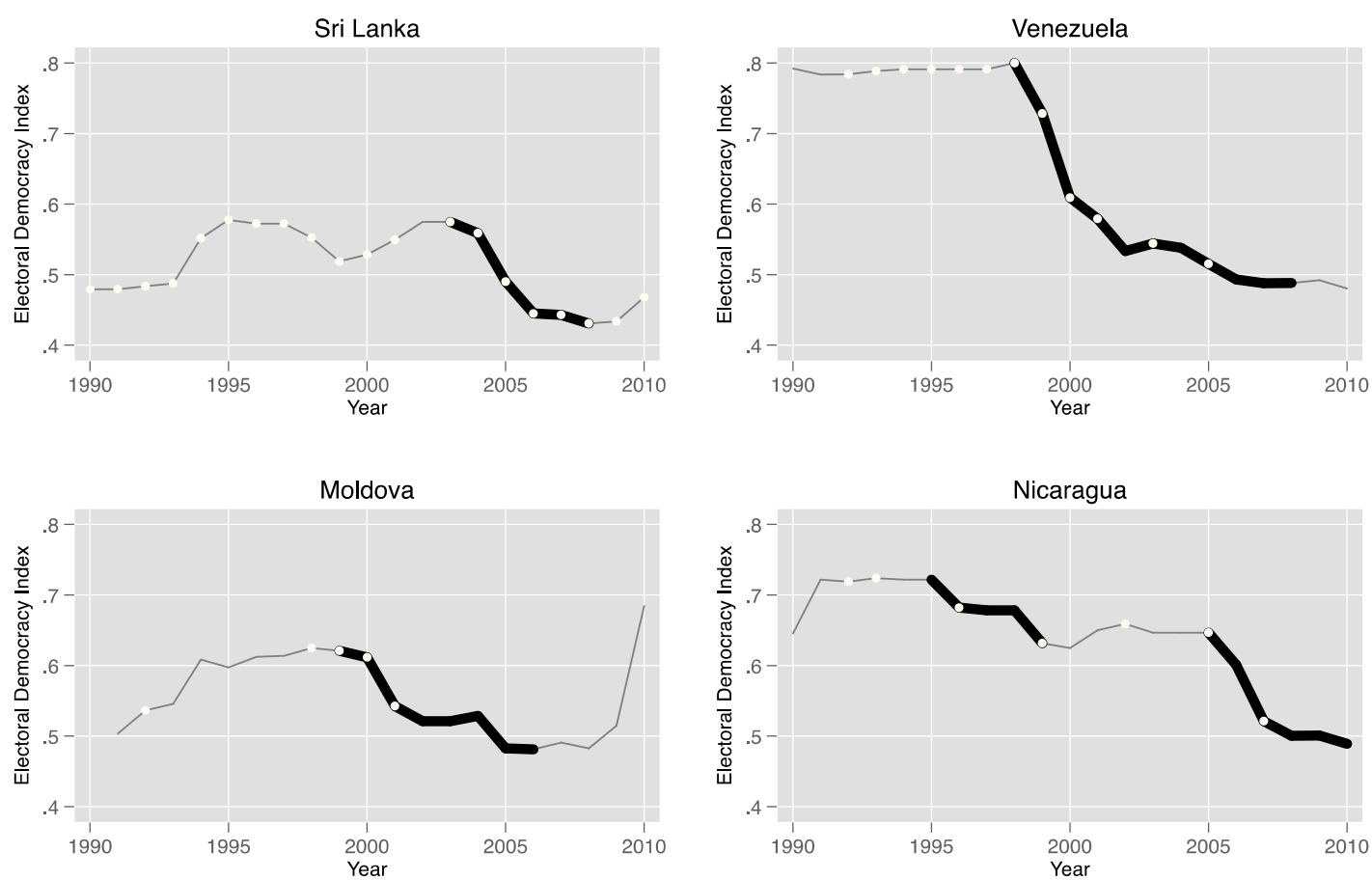

Note: The y-axis represents the electoral democracy index. Thick black lines indicate autocratization episodes and white circles indicate states of emergency.

Most confounders show the expected relationships. Autocratization episodes are less likely to occur the more democratic a country is, as well as the more it grows and prospers economically. Income inequality is associated with a lower risk of autocratization, which supports the idea that right-leaning elites may lead autocratization efforts in more egalitarian societies. We find no significant effects for political corruption, globalization, or oil rents. As expected, autocratization is more likely in later years of the sample.

\section{Robustness Analysis}

For robustness purposes, we estimate Model 2 with year-fixed effects (see Table 2 in the appendix). Findings hold even when looking solely at variance within years. ${ }^{66}$ We also estimate a model using a different dependent variable: the change in the V-Dem Electoral Democracy Index (EDI) in the year of a declaration of the state of emergency compared to the year prior in Table 3 (appendix). Findings again hold; a declaration of a state of emergency is associated with a statistically significant decline in the EDI.

${ }^{66}$ A model containing country-fixed effects drops too many observations for estimation to be considered valid, though the pattern found in each model is evident here as well. 
Table 1: Analyses of the Effect of States of Emergency on Autocratization

\begin{tabular}{|c|c|c|}
\hline & Autocratization Episode & Autocratization Episode \\
\hline & (1) & (2) \\
\hline Declared SOE & $0.386^{* * *}$ & $0.331 * *$ \\
\hline & $(0.107)$ & $(0.146)$ \\
\hline Liberal Component Index & & $\begin{array}{c}-4.087 * * * \\
(0.680)\end{array}$ \\
\hline Political Corruption Index & & 0.543 \\
\hline & & $(0.366)$ \\
\hline Gini Inequality Index (Disposable Income) & & $-0.016^{* *}$ \\
\hline & & $(0.008)$ \\
\hline Real GDPPC & & $-0.333 * *$ \\
\hline & & $(0.138)$ \\
\hline GDPPC Growth & & $-5.764 * * *$ \\
\hline & & $(1.236)$ \\
\hline Oil Rents & & 0.031 \\
\hline & & $(0.022)$ \\
\hline KOF Globalisation Index & & 0.001 \\
\hline & & $(0.006)$ \\
\hline Time & $0.036 * * *$ & $0.057 * * *$ \\
\hline & $(0.005)$ & $(0.010)$ \\
\hline Constant & $-72.819 * * *$ & $-112.119 * * *$ \\
\hline & $(10.331)$ & $(19.992)$ \\
\hline $\mathrm{N}$ & 2684 & 2127 \\
\hline
\end{tabular}

We also test the role of specific emergency provisions in driving autocratization. In Table 4 (appendix), rather than states of emergency, we examine the strength of the emergency powers given to the leader during a state of emergency. We take this variable from Rooney and the measure captures such variation as the breadth of declaration, the existence, scope, and depth of policy powers, as well as limitations on powers via institutional oversight and the expiration of the policies and powers taken during the crisis. ${ }^{67}$

We find that the existence of stronger emergency powers increases the likelihood of autocratization. In Table 5 (appendix), we include both the declaration of a state of emergency and emergency power strength in the model. ${ }^{68}$

This allows us to test for the danger of the institutional mechanism of a state of emergency as such, in addition to the attractiveness of the specific powers granted therein. We find that the effects of the declaration persist even when controlling the effect of the emergency powers. This suggests

${ }^{67}$ For a full description of the procedure for calculating this measure, see Rooney 2019a.

${ }^{68}$ We have examined the possibility of an interaction between the two, but have found little evidence. 
that the declaration itself matters, even independent of the specific content of the emergency provisions.

While we focus on aspects of the state that might make a state of emergency particularly dangerous, it is also important to consider when a state of emergency is likely to be seen as legitimate. We do this in Table 6 (appendix). We argue that states of emergency are most likely to be considered legitimate when called in response to a natural disaster, an interstate military dispute, or a civil conflict. We control for each of these factors, and find that our results nonetheless hold.

To ensure the robustness of the results, we also narrow our sample in two ways. First, in Table 7 (appendix), we examine only cases of national political emergencies as coded by Hafner-Burton, Helfer, and Fariss. ${ }^{69}$ National political emergencies entail, on average, the greatest deviation from political norms and thus we would expect to see the mechanism most clearly at work here. We find the results are in fact stronger in such instances. Second, in Table 8 (appendix), we examine only those countries in which the ability to declare a state of emergency is an institutional feature of the democracy, again using data from Rooney, since such emergencies involve no deviation from the institutional rules of the game. ${ }^{70}$ We find that the results hold with similar magnitude and maintain significance.

We argue that states of emergency should increase the likelihood of autocratization beyond the effect of the emergency's inciting event. To consider this more deeply, we examine only those states of emergencies we believe could most be considered exogenous to the political process - those driven by natural disasters. While we concede that natural disasters may not be entirely exogenous to autocratization, the literature suggests their relationship is very much in question. For instance, while some in the literature might suggest a positive relation- ship with autocratization, as deaths resulting from a lack of disaster preparedness could lead to public protest, leader removal, and perhaps democratic decline, recent evidence suggests natural disasters can inspire future democratization. ${ }^{71}$ Further, these events are unanticipated, and thus not manipulable by the government itself, as noted by Bjørnskov and Voigt, and as such we argue they provide the best possible source of exogenous variation given the constraints inherent in our question. ${ }^{72}$

We model this relationship in two ways. First, we consider states of emergency driven by the presence of a natural disaster as coded by Hafner-Burton, Helfer \& Fariss in Table 9. ${ }^{73}$ We find that states of emergency driven by natural disasters still strongly predict autocratization. In Table 10, we

\footnotetext{
${ }^{69}$ Hafner-Burton et al.

${ }^{70}$ Rooney, 2019b.

71 Alejandro Quiroz Flores, and Alastair Smith, "Leader Survival and Natural Disasters." British Journal of Political Science, 43 (Oct. 2013), 821-843; Pelle Ahlerup, "Democratisation in the Aftermath of Natural Disasters", in Arne Bigsten, ed., Globalization and Development: Rethinking Interventions and Governance (London: Routledge, 2013).

72 Bjørnskov and Voigt, 2018.

${ }^{73}$ Hafner-Burton et al.. This model loses a number of observations, as the cited data source does not extend across the entire time frame examined in the primary model.
} 
instead use the existence of any natural disaster as a predictor of a state of emergency in an instrumental variable analysis. We find that natural disasters do predict the occurrence of a state of emergency, and again find strong support for the relationship between states of emergency and autocratization. This suggests that even if leaders themselves could not anticipate the emergency arising, they take advantage of the opportunities presented to them to expand their power. The relationship between states of emergency and autocratization persists regardless of the analysis chosen.

\section{Conclusions}

Autocratization episodes - the substantial decline of democratic regime attributes - are roughly 75 percent more likely to occur in years with declared states of emergency. This finding is robust to a number of different statistical tests and model specifications. States of emergency, of course, are more likely to be declared once a country is in crisis (e.g. Moldova in 1992), and therefore potentially in danger of institutional collapse. Yet that is just one pathway through which states of emergency drive democratic decline. States of emergency also present an opportunity structure for leaders to dismantle democratic institutions and resistance to autocratization. States of emergency are therefore more likely to be declared by a political leader who aims to circumvent democratic constraints (e.g. Chavez in Venezuela in 1999), and to be used to further that end (e.g. Erdoğan in 2016).

Consequently, the public should examine each declaration of a state of emergency with care. Observers should scrutinize the intent of the leader, how dire the situation declared to be an emergency really is and the subsequent use or abuse of the extraordinary powers. Fortunately, this is what happened in the United States after the declaration of a state of emergency by Donald Trump in February 2019. As noted, fifty-eight former senior security officials issued a joint letter criticizing his move. His strategy also faces legal and congressional hurdles. ${ }^{74}$ Our research shows that the skepticism towards his approach is warranted. Trump's decision to declare a state of emergency and thereby circumventing legal constraints has put the United States into the bad company of eroding democracies and opens the door for further democratic declines.

This first empirical investigation of the relationship between states of emergencies and autocratization suggests a strong relationship between a declared state of exception and democratic decay. Our study should serve as the launching point for additional investigations of this relationship. Future research should seek to shed more light on the conditions under which states

\footnotetext{
${ }^{74}$ Erica Werner, Seung Min Kim, Paul Kane and John Wagner, "House sponsor of resolution to nix emergency declaration acknowledges uphill battle on overriding expected Trump veto," Washington Post, Feb. 26, 2019 (https://www.washingtonpost.com/powerpost/house-sponsor-of-resolution-to-nix-emergencydeclaration-acknowledges-uphill-battle-on-overriding-expected-trump-veto/2019/02/26/22104532-39d211e9-aaae-69364b2ed137_story.html).
} 
of emergency are most likely to contribute to autocratization, and what characteristics of emergencies indicate that democracy is particularly in peril, as well as how the public responds to such derogations. Further, scholars should also examine which types of emergency provisions are more likely to help preserve democracy, and which types are instead likely to see democracy meet its demise. Such research will enable us to shed light on the conditions under which the latter type of state of emergency - the dangerous one - is likely to occur and consequently on how such risks could be mitigated. 


\section{Appendix}

Table 1.1 Autocratization Episodes and Democratic Breakdown

\begin{tabular}{|c|c|c|c|c|}
\hline Country & Start Year & End Year & $\begin{array}{l}\text { Break } \\
\text { Down }\end{array}$ & SOE \\
\hline Argentina & 1975 & 1977 & 1 & 1 \\
\hline Armenia & 1993 & 1998 & 1 & 1 \\
\hline Bangladesh & 2002 & 2007 & 1 & 1 \\
\hline Belarus & 1995 & 2005 & 1 & 0 \\
\hline Bolivia & 2006 & 2015 & 0 & 1 \\
\hline Brazil & 2012 & 2016 & 0 & 0 \\
\hline Burkina Faso & 2014 & 2015 & 1 & 0 \\
\hline Chile & 1973 & 1975 & 1 & 1 \\
\hline Comoros & 1999 & 2000 & 1 & 0 \\
\hline Comoros & 2015 & 2016 & 1 & 0 \\
\hline Croatia & 2013 & 2016 & 0 & 0 \\
\hline $\begin{array}{l}\text { Dominican } \\
\text { Republic }\end{array}$ & 2015 & 2016 & 0 & 0 \\
\hline Ecuador & 2008 & 2010 & 0 & 1 \\
\hline Fiji & 1987 & 1988 & 1 & 0 \\
\hline Fiji & 2000 & 2001 & 1 & 1 \\
\hline Fiji & 2006 & 2009 & 1 & 1 \\
\hline Ghana & 1981 & 1982 & 1 & 0 \\
\hline Ghana & 2012 & 2016 & 0 & 0 \\
\hline Honduras & 2009 & 2010 & 1 & 0 \\
\hline Hungary & 2010 & 2016 & 0 & 0 \\
\hline India & 1971 & 1975 & 1 & 1 \\
\hline Lesotho & 2015 & 2016 & 0 & 0 \\
\hline Libya & 2014 & 2016 & 1 & 0 \\
\hline Macedonia & 2005 & 2012 & 1 & 1 \\
\hline Madagascar & 1997 & 2002 & 1 & 1 \\
\hline Malawi & 1999 & 2005 & 1 & 1 \\
\hline Mali & 2012 & 2013 & 1 & 1 \\
\hline Moldova & 2000 & 2006 & 1 & 1 \\
\hline Moldova & 2012 & 2016 & 0 & 0 \\
\hline Nepal & 2012 & 2013 & 1 & 0 \\
\hline Nicaragua & 1996 & 1999 & 0 & 1 \\
\hline Nicaragua & 2003 & 2016 & 1 & 1 \\
\hline Niger & 1995 & 1996 & 1 & 1 \\
\hline
\end{tabular}




\begin{tabular}{|l|l|l|l|l|}
\hline Niger & 2009 & 2010 & 1 & 1 \\
\hline Niger & 2013 & 2016 & 0 & 0 \\
\hline Peru & 1990 & 1992 & 1 & 1 \\
\hline Philippines & 2001 & 2005 & 1 & 1 \\
\hline Poland & 2013 & 2016 & 0 & 0 \\
\hline Russia & 1993 & 2016 & 1 & 1 \\
\hline Solomon Islands & 1997 & 2001 & 1 & 1 \\
\hline South Korea & 2008 & 2014 & 0 & 0 \\
\hline Spain & 2013 & 2016 & 0 & 0 \\
\hline Sri Lanka & 1977 & 1983 & 1 & 1 \\
\hline Sri Lanka & 2004 & 2008 & 1 & 1 \\
\hline Suriname & 1980 & 1981 & 1 & 1 \\
\hline Thailand & 2005 & 2007 & 1 & 1 \\
\hline Thailand & 2013 & 2016 & 1 & 1 \\
\hline Turkey & 1977 & 1981 & 1 & 0 \\
\hline Turkey & 2008 & 2016 & 1 & 1 \\
\hline Ukraine & 1997 & 2002 & 1 & 0 \\
\hline Ukraine & 2010 & 2015 & 1 & 0 \\
\hline Uruguay & 1968 & 1974 & 1 & 1 \\
\hline Venezuela & 1999 & 2008 & 1 & 1 \\
\hline Zambia & 2010 & 2016 & 1 & 0 \\
\hline & & & & \\
\hline
\end{tabular}

Table 1.2 Autocratization Episodes and Democratic Breakdown Summary

\begin{tabular}{|l|l|l|}
\hline & No Breakdown & Breakdown \\
\hline No State of Emergency & 11 & 13 \\
\hline State of Emergency & 3 & 27 \\
\hline
\end{tabular}


Table 1.3 Changes in Elements of Democracy

\begin{tabular}{|c|c|c|c|c|c|c|c|c|c|}
\hline Country & $\begin{array}{l}\text { Start } \\
\text { Year }\end{array}$ & $\begin{array}{l}\text { End } \\
\text { Year }\end{array}$ & $\begin{array}{l}\text { Break } \\
\text { Down }\end{array}$ & SOE & Expression & Association & Suffrage & $\begin{array}{l}\text { Free } \\
\text { and } \\
\text { Fair }\end{array}$ & \begin{tabular}{|l} 
Elected \\
Officials
\end{tabular} \\
\hline Argentina & 1975 & 1977 & 1 & 1 & 1 & 1 & 0 & 1 & 1 \\
\hline Armenia & 1993 & 1998 & 1 & 1 & 1 & 1 & 0 & 1 & 0 \\
\hline Bangladesh & 2002 & 2007 & 1 & 1 & 1 & 1 & 0 & 1 & 1 \\
\hline Belarus & 1995 & 2005 & 1 & 0 & 1 & 1 & 0 & 1 & 0 \\
\hline Bolivia & 2006 & 2015 & 0 & 1 & 1 & 1 & 0 & 1 & 0 \\
\hline Brazil & 2012 & 2016 & 0 & 0 & 0 & 0 & 0 & 0 & 0 \\
\hline Burkina Faso & 2014 & 2015 & 1 & 0 & 0 & 0 & 0 & 0 & 0 \\
\hline Chile & 1973 & 1975 & 1 & 1 & 1 & 1 & 0 & 1 & 0 \\
\hline Comoros & 1999 & 2000 & 1 & 0 & 0 & 0 & 0 & 1 & 0 \\
\hline Comoros & 2015 & 2016 & 1 & 0 & 0 & 0 & 0 & 0 & 0 \\
\hline Croatia & 2013 & 2016 & 0 & 0 & 1 & 0 & 0 & 0 & 0 \\
\hline $\begin{array}{l}\text { Dominican } \\
\text { Republic }\end{array}$ & 2015 & 2016 & 0 & 0 & 0 & 0 & 0 & 0 & 0 \\
\hline Ecuador & 2008 & 2010 & 0 & 1 & 1 & 0 & 0 & 1 & 0 \\
\hline Fiji & 1987 & 1988 & 1 & 0 & 0 & 0 & 0 & 1 & 0 \\
\hline Fiji & 2000 & 2001 & 1 & 1 & 0 & 0 & 0 & 0 & 0 \\
\hline Fiji & 2006 & 2009 & 1 & 1 & 1 & 1 & 0 & 1 & 0 \\
\hline Ghana & 1981 & 1982 & 1 & 0 & 1 & 1 & 0 & 0 & 0 \\
\hline Ghana & 2012 & 2016 & 0 & 0 & 0 & 0 & 0 & 1 & 0 \\
\hline Honduras & 2009 & 2010 & 1 & 0 & 0 & 0 & 0 & 1 & 0 \\
\hline Hungary & 2010 & 2016 & 0 & 0 & 1 & 0 & 0 & 1 & 0 \\
\hline India & 1971 & 1975 & 1 & 1 & 1 & 1 & 0 & 0 & 0 \\
\hline Lesotho & 2015 & 2016 & 0 & 0 & 0 & 0 & 0 & 0 & 0 \\
\hline Libya & 2014 & 2016 & 1 & 0 & 0 & 0 & 0 & 0 & 0 \\
\hline Macedonia & 2005 & 2012 & 1 & 1 & 1 & 0 & 0 & 1 & 0 \\
\hline Madagascar & 1997 & 2002 & 1 & 1 & 0 & 1 & 0 & 0 & 0 \\
\hline Malawi & 1999 & 2005 & 1 & 1 & 0 & 0 & 0 & 1 & 0 \\
\hline Mali & 2012 & 2013 & 1 & 1 & 0 & 0 & 0 & 0 & 0 \\
\hline Moldova & 2000 & 2006 & 1 & 1 & 0 & 1 & 0 & 1 & 0 \\
\hline Moldova & 2012 & 2016 & 0 & 0 & 1 & 1 & 0 & 1 & 0 \\
\hline Nepal & 2012 & 2013 & 1 & 0 & 1 & 0 & 0 & 0 & 0 \\
\hline Nicaragua & 1996 & 1999 & 0 & 1 & 0 & 0 & 0 & 1 & 0 \\
\hline Nicaragua & 2003 & 2016 & 1 & 1 & 1 & 1 & 0 & 1 & 0 \\
\hline Niger & 1995 & 1996 & 1 & 1 & 0 & 0 & 0 & 1 & 1 \\
\hline Niger & 2009 & 2010 & 1 & 1 & 0 & 1 & 0 & 1 & 1 \\
\hline Niger & 2013 & 2016 & 0 & 0 & 0 & 0 & 0 & 1 & 0 \\
\hline
\end{tabular}




\begin{tabular}{|l|l|l|l|l|l|l|l|l|l|}
\hline Peru & 1990 & 1992 & 1 & 1 & 0 & 0 & 0 & 0 & 1 \\
\hline Philippines & 2001 & 2005 & 1 & 1 & 1 & 0 & 0 & 1 & 0 \\
\hline Poland & 2013 & 2016 & 0 & 0 & 0 & 1 & 0 & 0 & 0 \\
\hline Russia & 1993 & 2016 & 1 & 1 & 1 & 1 & 0 & 1 & 0 \\
\hline $\begin{array}{l}\text { Solomon } \\
\text { Islands }\end{array}$ & 1997 & 2001 & 1 & 1 & 0 & 1 & 0 & 0 & 0 \\
\hline South Korea & 2008 & 2014 & 0 & 0 & 1 & 0 & 0 & 1 & 0 \\
\hline Spain & 2013 & 2016 & 0 & 0 & 0 & 0 & 0 & 0 & 0 \\
\hline Sri Lanka & 1977 & 1983 & 1 & 1 & 1 & 1 & 0 & 1 & 0 \\
\hline Sri Lanka & 2004 & 2008 & 1 & 1 & 1 & 0 & 0 & 1 & 0 \\
\hline Suriname & 1980 & 1981 & 1 & 1 & 1 & 1 & 0 & 1 & 0 \\
\hline Thailand & 2005 & 2007 & 1 & 1 & 1 & 1 & 0 & 0 & 1 \\
\hline Thailand & 2013 & 2016 & 1 & 1 & 0 & 0 & 0 & 0 & 0 \\
\hline Turkey & 1977 & 1981 & 1 & 0 & 1 & 1 & 0 & 1 & 1 \\
\hline Turkey & 2008 & 2016 & 1 & 1 & 1 & 0 & 0 & 1 & 0 \\
\hline Ukraine & 1997 & 2002 & 1 & 0 & 1 & 0 & 0 & 1 & 0 \\
\hline Ukraine & 2010 & 2015 & 1 & 0 & 1 & 1 & 0 & 1 & 0 \\
\hline Uruguay & 1968 & 1974 & 1 & 1 & 1 & 0 & 1 & 1 & 0 \\
\hline Venezuela & 1999 & 2008 & 1 & 1 & 1 & 1 & 1 & 0 \\
\hline Zambia & 2010 & 2016 & 1 & 0 & 1 & 0 & 1 & 0 \\
\hline
\end{tabular}


Table 2- Analyses of the Effect of States of Emergency on Autocratization

\begin{tabular}{|lcc|}
\hline & $(1)$ & $(2)$ \\
& Autocratization Episode & Autocratization Episode \\
Declared SOE & $0.386^{* * *}$ & $0.302^{* *}$ \\
Time & $(0.135)$ & $(0.153)$ \\
& $0.0355^{* * *}$ & $0.0684^{* * *}$ \\
Liberal Component Index & $(0.00496)$ & $(0.0104)$ \\
& & $-4.087^{* * *}$ \\
Political Corruption Index & & $(0.680)$ \\
Gini Inequality Index & & $-0.974^{* * *}$ \\
(Disposable Income) & & $(0.367)$ \\
Real GDPPC & & $-0.0229 * * *$ \\
GDPPC Growth & & $(0.00660)$ \\
Oil Rents & & $-0.452^{* * *}$ \\
Economic Globalization & & $(0.105)$ \\
Constant & & $-3.163^{* *}$ \\
Observations & & $(1.398)$ \\
& & 0.00169 \\
& & $(0.0187)$ \\
& $(9.949)$ & 0.00130 \\
& 2684 & $(0.00645)$ \\
& & $-130.2^{* * *}$ \\
& & $(21.21)$ \\
& & 2076 \\
\hline
\end{tabular}


Table 3: Analysis of the Effect of States of Emergency on Electoral Democracy Index Electoral Democracy Index

\begin{tabular}{lc}
\hline & $(1)$ \\
Declared SOE & $-0.007^{* * *}$ \\
Liberal Democracy Index & $(0.002)$ \\
Gini Inequality Index (Disposable Income) & $-0.094^{* * *}$ \\
& $(0.021)$ \\
Real GDPPC & -0.000 \\
GDPPC Growth & $(0.000)$ \\
Oil Rents & $0.009^{* * *}$ \\
& $(0.002)$ \\
KOF Globalisation Index & 0.022 \\
Time & $(0.019)$ \\
Constant & $-0.001^{* * *}$ \\
& $(0.000)$ \\
\hline $\mathrm{N}$ & 0.000 \\
\hline Notes: Robust stant & $(0.000)$ \\
\end{tabular}

Notes: Robust standard errors in parentheses. All controls are lagged by one year.

$* p<0.10,{ }^{* *} p<0.05,{ }^{* * *} p<.01$ 
Table 4: Analysis of the Effect of Emergency Powers on Autocratization

\begin{tabular}{lc}
\hline & Autocratization Episode \\
\cline { 2 - 2 } & $(1)$ \\
\hline Emergency Powers & $0.222^{* *}$ \\
Liberal Democracy Index & $(0.089)$ \\
Political Corruption Index & $-2.809^{* * *}$ \\
Gini Inequality Index (Disposable Income) & $(0.874)$ \\
& -0.084 \\
Real GDPPC & $(0.444)$ \\
GDPPC Growth & $-0.021^{* *}$ \\
Oil Rents & $(0.008)$ \\
KOF Globalisation Index & $-0.443^{* * *}$ \\
Time & $(0.164)$ \\
Constant & $-3.961^{* *}$ \\
& $(1.763)$ \\
\hline N & $0.088^{* * *}$ \\
\hline Note: Boor & $(0.018)$ \\
& 0.020 \\
& $(0.014)$ \\
& $0.065^{* * *}$ \\
& $(0.015)$ \\
& $-126.380^{* * *}$ \\
& $(29.877)$ \\
\hline
\end{tabular}

Notes: Bootstrapped standard errors in parentheses. All controls are lagged by one year.

$* p<0.10, * * p<0.05, * * * p<.01$ 
Table 5: Analysis of the Effect of States of Emergency and Emergency Powers on Autocratization

\begin{tabular}{|c|c|}
\hline & \multirow{2}{*}{$\begin{array}{c}\text { Autocratization Episode } \\
(1)\end{array}$} \\
\hline & \\
\hline Declared SOE & $\begin{array}{l}0.277^{*} \\
(0.165)\end{array}$ \\
\hline Emergency Powers & $\begin{array}{l}0.184^{* *} \\
\quad(0.076)\end{array}$ \\
\hline Liberal Democracy Index & $\begin{array}{r}-2.148^{* *} \\
(0.868)\end{array}$ \\
\hline Political Corruption Index & $\begin{array}{c}0.332 \\
(0.427)\end{array}$ \\
\hline Gini Inequality Index (Disposable Income) & $\begin{array}{l}-0.016^{*} \\
(0.009)\end{array}$ \\
\hline Real GDPPC & $\begin{array}{r}-0.640 * * * \\
(0.162)\end{array}$ \\
\hline GDPPC Growth & $\begin{array}{r}-5.196 * * * \\
(1.742)\end{array}$ \\
\hline Oil Rents & $\begin{array}{l}0.103 * * * \\
(0.020)\end{array}$ \\
\hline KOF Globalisation Index & $\begin{array}{l}0.030 * \\
(0.016)\end{array}$ \\
\hline Time & $\begin{array}{l}0.080^{* * *} \\
(0.013)\end{array}$ \\
\hline Constant & $\begin{array}{r}-156.853 * * * \\
(26.144)\end{array}$ \\
\hline $\mathrm{N}$ & 2028 \\
\hline
\end{tabular}

Notes: Bootstrapped standard errors in parentheses. All controls are lagged by one year.

$* p<0.10,{ }^{* *} p<0.05,{ }^{* * *} p<.01$ 
Table 6: Analysis with Controls for "Legitimate" States of Emergency

\begin{tabular}{|c|c|}
\hline & \multirow{2}{*}{$\begin{array}{c}\text { Autocratization Episode } \\
(1)\end{array}$} \\
\hline & \\
\hline Declared SOE & $\begin{array}{l}0.437 * * \\
(0.211)\end{array}$ \\
\hline Liberal Democracy Index & $\begin{array}{c}-3.702^{* * *} \\
(0.968)\end{array}$ \\
\hline Political Corruption Index & $\begin{array}{c}0.651 \\
(0.629)\end{array}$ \\
\hline Gini Inequality Index (Disposable Income) & $\begin{array}{l}-0.011 \\
\quad(0.014)\end{array}$ \\
\hline Real GDPPC & $\begin{array}{r}-0.832 * * * \\
(0.225)\end{array}$ \\
\hline GDPPC Growth & $\begin{array}{r}-8.583 * * * \\
(2.053)\end{array}$ \\
\hline Oil Rents & $\begin{array}{l}0.115^{* * *} \\
(0.026)\end{array}$ \\
\hline KOF Globalisation Index & $\begin{array}{l}0.032 \\
(0.020)\end{array}$ \\
\hline Natural Disaster & $\begin{array}{l}0.164 \\
(0.322)\end{array}$ \\
\hline Militarized Interstate Dispute & $\begin{array}{l}0.508^{*} \\
(0.308)\end{array}$ \\
\hline Civil War & $\begin{array}{l}0.239 \\
(0.239)\end{array}$ \\
\hline Time & $\begin{array}{l}0.095^{* * *} \\
(0.024)\end{array}$ \\
\hline Constant & $\begin{array}{r}-184.603 * * * \\
(47.878)\end{array}$ \\
\hline $\mathrm{N}$ & 1602 \\
\hline
\end{tabular}

Notes: Bootstrapped standard errors in parentheses. Standard controls are lagged by one year.

"Legitimate" SOE controls concurrent with state of emergency.

${ }^{*} p<0.10,{ }^{* *} p<0.05,{ }^{* * *} p<.01$ 
Table 7: Analysis of the Effect of National Political States of Emergency on Autocratization

\begin{tabular}{|c|c|}
\hline & Autocratization Episode \\
\hline & (1) \\
\hline \multirow[t]{2}{*}{ National Political SOE } & $0.573^{* *}$ \\
\hline & $(0.269)$ \\
\hline \multirow[t]{2}{*}{ Liberal Democracy Index } & -1.852 \\
\hline & $(1.278)$ \\
\hline \multirow[t]{2}{*}{ Political Corruption Index } & $2.173^{* *}$ \\
\hline & $(0.877)$ \\
\hline \multirow[t]{2}{*}{ Gini Inequality Index (Disposable Income) } & -0.011 \\
\hline & $(0.012)$ \\
\hline \multirow[t]{2}{*}{ Real GDPPC } & -0.422 \\
\hline & $(0.264)$ \\
\hline \multirow[t]{2}{*}{ GDPPC Growth } & $-8.194 * * *$ \\
\hline & $(2.416)$ \\
\hline \multirow[t]{2}{*}{ Oil Rents } & 0.020 \\
\hline & $(0.060)$ \\
\hline \multirow[t]{2}{*}{ KOF Globalisation Index } & 0.002 \\
\hline & $(0.020)$ \\
\hline \multirow[t]{2}{*}{ Time } & $0.067^{* *}$ \\
\hline & $(0.028)$ \\
\hline \multirow[t]{2}{*}{ Constant } & $-131.923 * *$ \\
\hline & $(55.552)$ \\
\hline $\mathrm{N}$ & 1391 \\
\hline
\end{tabular}

Notes: Bootstrapped standard errors in parentheses. All controls are lagged by one year.

$* p<0.10, * * p<0.05, * * * p<.01$ 
Table 8: Analysis of the Effect of Institutional States of Emergency on Autocratization

\begin{tabular}{|c|c|}
\hline & \multirow{2}{*}{$\begin{array}{c}\text { Autocratization Episode } \\
(1)\end{array}$} \\
\hline & \\
\hline Declared SOE & $\begin{array}{c}0.313^{* *} \\
(0.158)\end{array}$ \\
\hline Liberal Democracy Index & $\begin{array}{c}-2.292^{* * *} \\
(0.802)\end{array}$ \\
\hline Political Corruption Index & $\begin{array}{c}0.118 \\
(0.383)\end{array}$ \\
\hline Gini Inequality Index (Disposable Income) & $\begin{array}{r}-0.018^{* *} \\
(0.008)\end{array}$ \\
\hline Real GDPPC & $\begin{array}{r}-0.606 * * * \\
(0.157)\end{array}$ \\
\hline GDPPC Growth & $\begin{array}{r}-4.893 * * * \\
(1.534)\end{array}$ \\
\hline Oil Rents & $\begin{array}{l}0.106^{* * *} \\
(0.018)\end{array}$ \\
\hline KOF Globalisation Index & $\begin{array}{l}0.028^{*} \\
(0.015)\end{array}$ \\
\hline Time & $\begin{array}{l}0.079 * * * \\
(0.012)\end{array}$ \\
\hline Constant & $\begin{array}{c}-154.209 * * * \\
(25.145)\end{array}$ \\
\hline $\mathrm{N}$ & 1683 \\
\hline
\end{tabular}

Notes: Bootstrapped standard errors in parentheses. All controls are lagged by one year.

$* p<0.10,{ }^{* *} p<0.05,{ }^{* * *} p<.01$ 
Table 9: Analysis of the Effect of Natural Disaster States of Emergency on Autocratization

\begin{tabular}{lc}
\hline & Autocratization Episode \\
\cline { 2 - 2 } Natural Disaster SOE & $(1)$ \\
Liberal Democracy Index & $0.535^{* *}$ \\
Political Corruption Index & $(0.264)$ \\
& $-2.390^{*}$ \\
Gini Inequality Index (Disposable Income) & $(1.259)$ \\
Real GDPPC & $2.004^{* *}$ \\
GDPPC Growth & $(0.938)$ \\
Oil Rents & -0.014 \\
KOF Globalisation Index & $(0.011)$ \\
Time & -0.253 \\
Constant & $(0.224)$ \\
& $-8.152^{* * *}$ \\
N & $(2.421)$ \\
& 0.031 \\
& $(0.061)$ \\
& 0.001 \\
& $(0.020)$ \\
& $0.053^{*}$ \\
& $(0.029)$ \\
& $-104.451 *$ \\
& $(57.069)$ \\
\hline
\end{tabular}

Notes: Bootstrapped standard errors in parentheses. All controls are lagged by one year.

$* p<0.10,{ }^{* *} p<0.05, * * * p<.01$ 
Table 10: Instrumental Variable Analysis: States of Emergency and Autocratization

\section{Autocratization Episode}

(1)

\begin{tabular}{|c|c|}
\hline Declared SOE & $\begin{array}{c}2.710^{* * *} \\
(0.240)\end{array}$ \\
\hline Liberal Democracy Index & $\begin{array}{c}0.079 \\
(0.764)\end{array}$ \\
\hline Political Corruption Index & $\begin{array}{l}-0.201 \\
(0.275)\end{array}$ \\
\hline Gini Inequality Index (Disposable Income) & $\begin{array}{c}-0.036 * * * \\
(0.004)\end{array}$ \\
\hline Real GDPPC & $\begin{array}{l}-0.146 \\
(0.113)\end{array}$ \\
\hline GDPPC Growth & $\begin{array}{l}-2.448 \\
(1.514)\end{array}$ \\
\hline Oil Rents & $\begin{array}{l}-0.010 \\
(0.017)\end{array}$ \\
\hline KOF Globalisation Index & $\begin{array}{c}-0.025^{* *} \\
(0.010)\end{array}$ \\
\hline Time & $\begin{array}{c}0.055^{* * *} \\
(0.010)\end{array}$ \\
\hline Constant & $\begin{array}{c}-106.077^{* * *} \\
(20.820)\end{array}$ \\
\hline Natural Disaster & $\begin{array}{c}0.049 * * * \\
(0.015)\end{array}$ \\
\hline $\mathrm{N}$ & 2057 \\
\hline
\end{tabular}

Notes: Jackknife standard errors in parentheses. All controls are lagged by one year.

$* p<0.10,{ }^{* *} p<0.05,{ }^{* * *} p<.01$ 
Table 11: Lagged State of Emergency

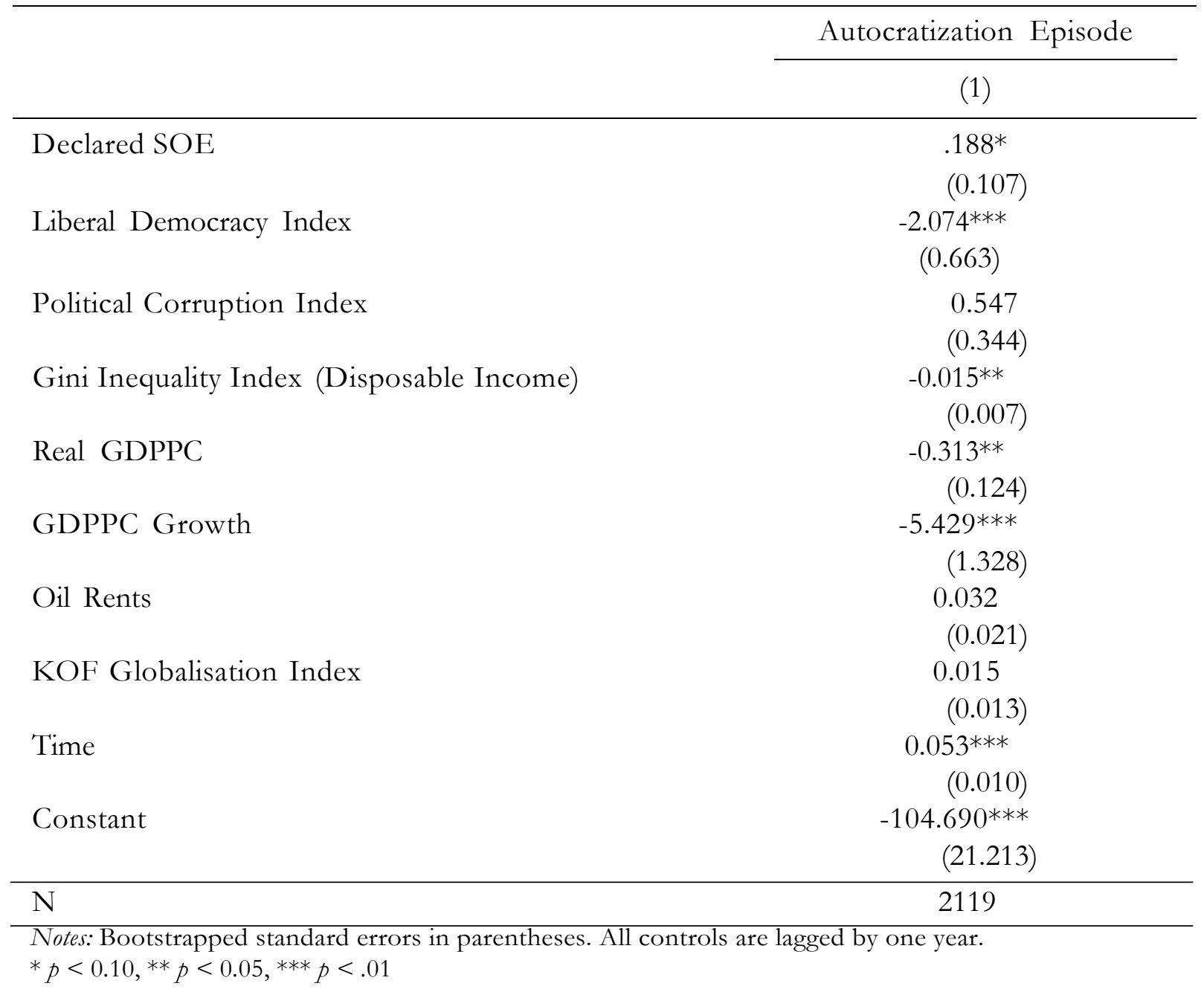

